Katarzyna Podhorodecka

University of Warsaw - Faculty of Geography and Regional Studies

Institute of Regional and Global Studies

e-mail: kpodhorodecka@yahoo.com

\title{
VARIETY OF ECONOMIC SHARE OF TOURISM ON TROPICAL ISLANDS
}

\begin{abstract}
The author seeks an answer to the question whether a higher intensity of tourism movement is connected with a higher share of tourism in the economy in selected tropical island territories. With the use of the Spearman correlation coefficient, the existence of the average positive correlation between the intensity of tourism movement and the share of tourism in the economy has been determined. In the second part of paper, the author looks at the conditions which affect the role of tourism in the economy in proportion to the intensity of tourism movement. For this purpose, the Chi-square test and detailed case studies of chosen tropical islands are discussed.
\end{abstract}

Key words: tropical islands, economic significance of tourism, tourism intensity.

\section{INTRODUCTION}

The aim of the article is to find the answer to the question: Is a higher intensity of tourism movement connected with a higher share of tourism in the economy for chosen tropical island territories? The author put forward two hypotheses. Hypothesis I - The share of tourism in the economy of tropical island states and dependencies is not strictly connected with the intensity of tourism movement. On the one hand, there are island territories which, despite a high intensity of tourism movement, have a smaller share of tourism in the economy. On the other, there exist island territories which, despite a smaller intensity of tourism movement, have a bigger share of tourism in the economy. Secondly, the study aims to find the answer to the question: What conditions affect the differentiation of the share of tourism in the economy in proportion to the intensity of tourism movement and which of them are the most important ones? The second hypothesis was: The diversity of the economy exerts the strongest influence on the share of tourism in 
the economy in proportion to the intensity of tourism movement for chosen tropical island territories.

\section{METHODS, TERRITORIAL AND TEMPORAL RANGE}

In the research, the following methods were used: the Spearman correlation coefficient and standardisation method; typology; cross table analysis; Chi-square test and analysis of case studies. Territorially, there were 30 island territories in the tropical zone (both independent and dependent territories). The selected tropical territories occupied an area smaller than 30,000 square kilometres, and had a population under 4 million. The conditions of tourism economy on tropical island territories at the beginning of the $21^{\text {st }}$ century are described in the paper (with 2004 as the base year) ${ }^{1}$.

Table 1. Chosen measures of tourism intensity movement and economic significance of tourism for tropical island territories in 2004

\begin{tabular}{|l|r|r|r|r|}
\hline \multirow{2}{*}{$\begin{array}{c}\text { Chosen tropical Island } \\
\text { territories }\end{array}$} & \multirow{2}{*}{$\begin{array}{c}\text { Tourism } \\
\text { intensity } \\
\text { ratio }\end{array}$} & $\begin{array}{c}\text { GDP } \\
(\%)\end{array}$ & $\begin{array}{c}\text { TSA - Share of tourism in } \\
(\%)\end{array}$ & $\begin{array}{c}\text { export } \\
(\%)\end{array}$ \\
\cline { 3 - 5 } & 2409 & 31.4 & 37.3 & 38.2 \\
\hline American Virgin Islands & 930 & 67.8 & 73.1 & 78.9 \\
\hline Anguilla & 1213 & 81.5 & 95.0 & 70.5 \\
\hline Antigua and Barbuda & 1831 & 68.9 & 83.0 & 31.1 \\
\hline Aruba & 457 & 44.2 & 50.5 & 54.8 \\
\hline Barbados & 3664 & 95.2 & 95.0 & 64.0 \\
\hline British Virgin Islands & 667 & 23.9 & 21.8 & 35.1 \\
\hline Dominica & 57 & 26.5 & 24.6 & 34.0 \\
\hline Fiji & 414 & 22.4 & 20.8 & 27.5 \\
\hline Grenada & 132 & 25.5 & 23.8 & 22.0 \\
\hline Guadalupe & 93 & 33.1 & 29.2 & 44.4 \\
\hline Jamaica & 4531 & 44.6 & 55.1 & 47.2 \\
\hline Cayman Islands & 62 & 23.1 & 18.9 & 19.3 \\
\hline Kiribati & 3 & 10.2 & 8.3 & 18.2 \\
\hline Comoros & 182 & 70.8 & 61.5 & 69.4 \\
\hline Maldives & 147 & 8.8 & 9.2 & 13.6 \\
\hline Martinique & 61 & 29.2 & 31.2 & 33.2 \\
\hline Mauritius & 125 & 5.6 & 5.7 & 7.3 \\
\hline Puerto Rico & 38 & 19.5 & 17.8 & 51.6 \\
\hline Cape Verde & 56 & 5.7 & 6.4 & 4.0 \\
\hline Reunion & 971 & 26.5 & 26.8 & 38.0 \\
\hline Saint Kitts and Nevis & & & & \\
\hline
\end{tabular}

${ }^{1}$ All of the described tropical island territories published comparable data for the year 2004 The changes of the share of tourism in the economy for particular tropical islands as compared to the previous years are not significant. Therefore the author used the data from the year 2004 as the base year. 


\begin{tabular}{|l|r|r|r|r|}
\hline Saint Lucia & 482 & 39.7 & 40.0 & 77.2 \\
\hline Saint Vincent and Grenadines & 224 & 30.5 & 27.3 & 47.6 \\
\hline Seychelles & 158 & 52.9 & 66.9 & 45.9 \\
\hline Tonga & 37 & 13.3 & 11.5 & 31.2 \\
\hline Trinidad and Tobago & 45 & 10.5 & 10.3 & 13.8 \\
\hline Vanuatu & 49 & 38.0 & 34.1 & 48.8 \\
\hline Bahamas & 2179 & 51.0 & 64.3 & 68.6 \\
\hline Solomon Islands & 1 & 9.3 & 7.7 & 6.7 \\
\hline Saõ Tome and Principe & 4 & 24.3 & 19.4 & 53.5 \\
\hline
\end{tabular}

Source: prepared by the author based on: Compendium of tourism statistics, 2006, WTO, Madrid; World, travel and tourism sowing the seeds of growth, WTTC, 2005, pp. 5-27; Recommendations on tourism statistics, 1994, p. 15.

\section{THE CORRELATION BETWEEN THE INTENSITY OF TOURISM MOVEMENT AND THE SHARE OF TOURISM IN THE ECONOMY}

The intensity of tourism movement on tropical island territories has a positive influence on the share of tourism in GDP, employment and exports (the Spearman correlation coefficient was, respectively, 0.682; 0.739; 0.478; the correlation was significant at the level of 0.01). This influence was not the same for all tropical island territories. The tropical island territories with a bigger and smaller share of tourism in GDP, employment and export in proportion to the intensity of tourism movement were indicated (in confirmation of the first hypothesis).

The correlation between the intensity of tourism movement and the sum of the three standardised indicators of the share of tourism in economy was calculated. The Spearman correlation coefficient was $\mathbf{0 . 6 4 2}$, and indicated the existence of an average positive correlation between the intensity of tourism movement and the share of tourism in the economy.

Table 2. Correlation between the intensity of tourism movement and the share of tourism in GDP, employment and export and the sum of standardised measures

\begin{tabular}{|l|c|c|c|c|}
\hline & $\begin{array}{c}\text { I. Share of } \\
\text { tourism in } \\
\text { GDP }\end{array}$ & $\begin{array}{c}\text { II. Share of } \\
\text { tourism in } \\
\text { employment }\end{array}$ & $\begin{array}{c}\text { III. Share of } \\
\text { tourism in } \\
\text { export }\end{array}$ & $\begin{array}{c}\text { Share of tourism in the } \\
\text { economy (sum of three } \\
\text { standardised measures - } \\
\text { I+II+III) }\end{array}$ \\
\hline $\begin{array}{l}\text { Intensity } \\
\text { of tourism } \\
\text { movement }\end{array}$ & $0.682^{*}$ & $0.739^{*}$ & $0.478^{*}$ & $0.642^{*}$ \\
\hline $\begin{array}{l}\text { Correlation } \\
\text { value }\end{array}$ & $\begin{array}{c}\text { positive } \\
\text { average }\end{array}$ & $\begin{array}{l}\text { positive } \\
\text { significant }\end{array}$ & $\begin{array}{c}\text { positive } \\
\text { average }\end{array}$ & positive average \\
\hline
\end{tabular}

* Correlation is significant at the level of 0.01 . 


\section{THE VARIETY OF ANALYSED TROPICAL ISLAND TERRITORIES IN TERMS OF ECONOMICAL BENEFITS FROM TOURISM (TYPOLOGY)}

The variety of analysed tropical islands in terms of economic benefits was analysed by the development of a typology. Tropical island territories were divided into three types. Type A - tropical island territories with a higher share of tourism in proportion to the intensity of tourism movement, type $\mathrm{B}$ - tropical island territories with a proportional share, type $\mathrm{C}$ - with smaller.

Table 3. Comparison of typologies

\begin{tabular}{|c|c|c|c|c|}
\hline & \multicolumn{2}{|l|}{ Typology I } & \multicolumn{2}{|l|}{ Typology II } \\
\hline & Tropical island territories & Number & Tropical island territories & Number \\
\hline TYPE A & \begin{tabular}{|l} 
Fiji \\
Jamaica \\
Maldives \\
Mauritius \\
Cape Verde \\
Seychelles \\
Vanuatu \\
Saõ Tome and Principe
\end{tabular} & 8 & \begin{tabular}{|l|} 
Fiji \\
Jamaica \\
Kiribati \\
Maldives \\
Mauritius \\
Cape Verde \\
Saint Lucia \\
Seychelles \\
Tonga \\
Vanuatu \\
Saõ Tome and Principe
\end{tabular} & 11 \\
\hline TYPE B & $\begin{array}{l}\text { Anguilla } \\
\text { Antigua and Barbuda } \\
\text { Aruba } \\
\text { Barbados } \\
\text { British Virgin Islands } \\
\text { Guadalupe } \\
\text { Kiribati } \\
\text { Comoros } \\
\text { Saint Lucia } \\
\text { Saint Vincent and Grenadines } \\
\text { Tonga } \\
\text { Trinidad and Tobago } \\
\text { Bahamas } \\
\text { Solomon Islands }\end{array}$ & 14 & $\begin{array}{l}\text { Anguilla } \\
\text { Antigua and Barbuda } \\
\text { British Virgin Islands } \\
\text { Grenada } \\
\text { Guadalupe } \\
\text { Comoros } \\
\text { Reunion } \\
\text { Saint Vincent and } \\
\text { Grenadines } \\
\text { Trinidad and Tobago } \\
\text { Bahamas } \\
\text { Solomon Islands }\end{array}$ & 11 \\
\hline TYPE C & $\begin{array}{l}\text { American Virgin Islands } \\
\text { Dominica } \\
\text { Grenada } \\
\text { Cayman Islands } \\
\text { Martinique } \\
\text { Puerto Rico } \\
\text { Reunion } \\
\text { Saint Kitts and Nevis } \\
\end{array}$ & 8 & $\begin{array}{l}\text { American Virgin Islands } \\
\text { Aruba } \\
\text { Barbados } \\
\text { Dominica } \\
\text { Cayman Islands } \\
\text { Martinique } \\
\text { Puerto Rico } \\
\text { Saint Kitts and Nevis } \\
\end{array}$ & 8 \\
\hline
\end{tabular}

Blue colour indicates tropical island territories, which were classified in the same type in both methods, red colour - to different types. 
Two typologies are developed in the study. In typology I - classification into particular types based on the difference of ranks that the territories were given after being arranged in the order from the smaller to the bigger. In typology II - the classification into particular types was conducted on the basis of intervals for the three groups. The results of both typologies confirmed the hypothesis. The results of the second typology were used below because the division into groups was more equal.

Typology II was created on the basis of data concerning the intensity of tourism movement and the measures of the share of tourism in GDP, employment and export. Each of the factors was divided into three intervals based on the value of the measure. Low values received number - 1 , average values -2 , high values -3 .

This allowed for recording the intensity of the movement ratio and the values of the economic share as a code (one and three elements, respectively). The sum of the differences between the code for the intensity of tourism movement and the codes of particular measures showing the share of tourism in the economy produced values from 0 to 3 . As a result, tropical island territories were classified under specific subtypes: $\mathbf{A}_{3}, \mathbf{A}_{2}, \mathbf{A}_{1}, \mathbf{B}, \mathbf{C}_{1}$, $\mathrm{C}_{2}, \mathrm{C}_{3}$.

subtype $\mathbf{A}_{3}$ - difference 3 subtype $\mathbf{A}_{2}$ - difference 2 subtype $\mathbf{A}_{1}$ - difference 1

type $\mathbf{B}$ - difference 0

subtype $\mathbf{C}_{1}$ - difference 1 subtype $\mathbf{C}_{2}$ - difference 2 subtype $\mathbf{C}_{3}$ - difference 3 tropical island territories with a bigger share of tourism in the economy in proportion to the intensity of tourism movement

tropical island territories with an adequate share of tourism in the economy in proportion to the intensity of tourism movement

tropical island territories with a smaller share of tourism in the economy in proportion to the intensity of tourism movement

The tropical island territories analysed as case studies were classified into different types. Mauritius was classified as subtype $\mathrm{A}_{3}$, The Solomon Islands as subtype $\mathrm{B}$, and The Cayman Islands as subtype $\mathrm{C}_{2}$. In subtype $\mathrm{A}_{3}$, we classified island territories with the biggest share of tourism in the economy in proportion to the intensity of tourism movement (the higher value of codes for three measures: share of tourism in GDP, employment and export). In subtype $A_{2}$ - only two values of codes among the three for the analysed tropical island territories were bigger in proportion to the intensity of tourism movement, and in subtype $\mathrm{A}_{1}$ - only one. Subtype $\mathrm{C}_{3}$ grouped tropical island territories with a smaller share of tourism in the economy in proportion to the intensity of tourism movement (lower values 
of the three codes). In subtype $\mathrm{C}_{2}$, only two values of codes of three were smaller in proportion to the intensity of tourism movement, and in subtype $\mathrm{C}_{1}$ - only one. In type B, subtypes were not indicated because all the codes for the measures were proportional in relation to the codes for the intensity of tourism movement.

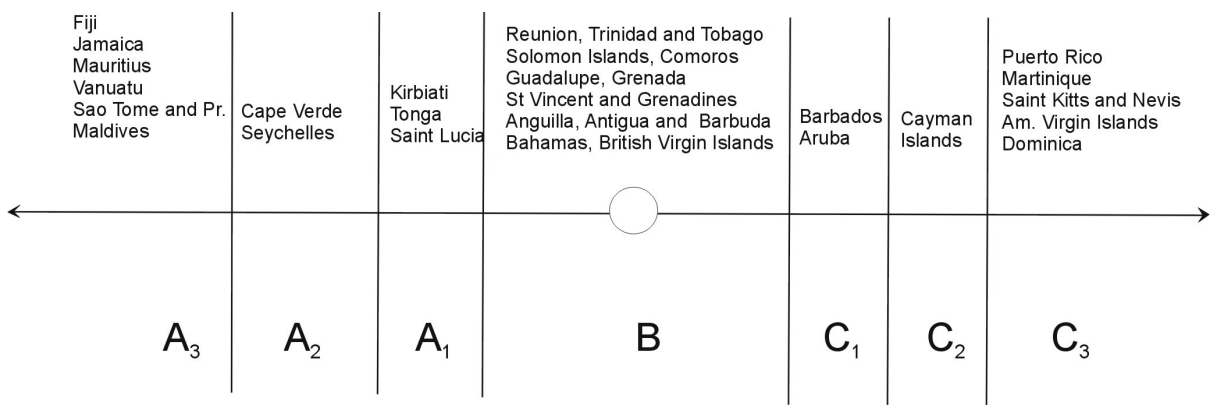

Fig. 2. Division of the analysed tropical island territories into subtypes

\section{CONDITIONS OF VARIETY OF ECONOMIC SHARE OF TOURISM}

The choice of potential conditions underlying the variety of the share of tourism in the economy was influenced by an assumption that geographical features such as: the size of the territory, its location, demographical features (number of citizens, population density and urbanisation) and political features (dependence or independence) may significantly affect the share of tourism in the economy. Moreover, it was assumed that tropical island territories with diversified economies should have a bigger share of tourism in GDP, employment and exports due to the possibility to provide diversified goods and services from the local economy. Below, the following types are characterised:

TYPE A - high or average diversification of the economy ratio, average or big surface area, average population, average or small population density, small or average length of stay ratio, high isolation indicator, average or small urbanisation, many independent countries, no dependent countries, location: Indian Ocean, Pacific Ocean, Eastern Atlantic.

TYPE B - low or high diversification of the economy ratio, large or small surface area, large or small population, small population density, high or average length of stay ratio, small isolation indicator, high or low urbanisation, independent countries and dependent states, location: mainly the Caribbean, two island territories in the Indian Ocean, one in the Pacific Ocean.

TYPE C - small or average diversification of the economy ratio, small surface area, small population, high population density, high length of stay 


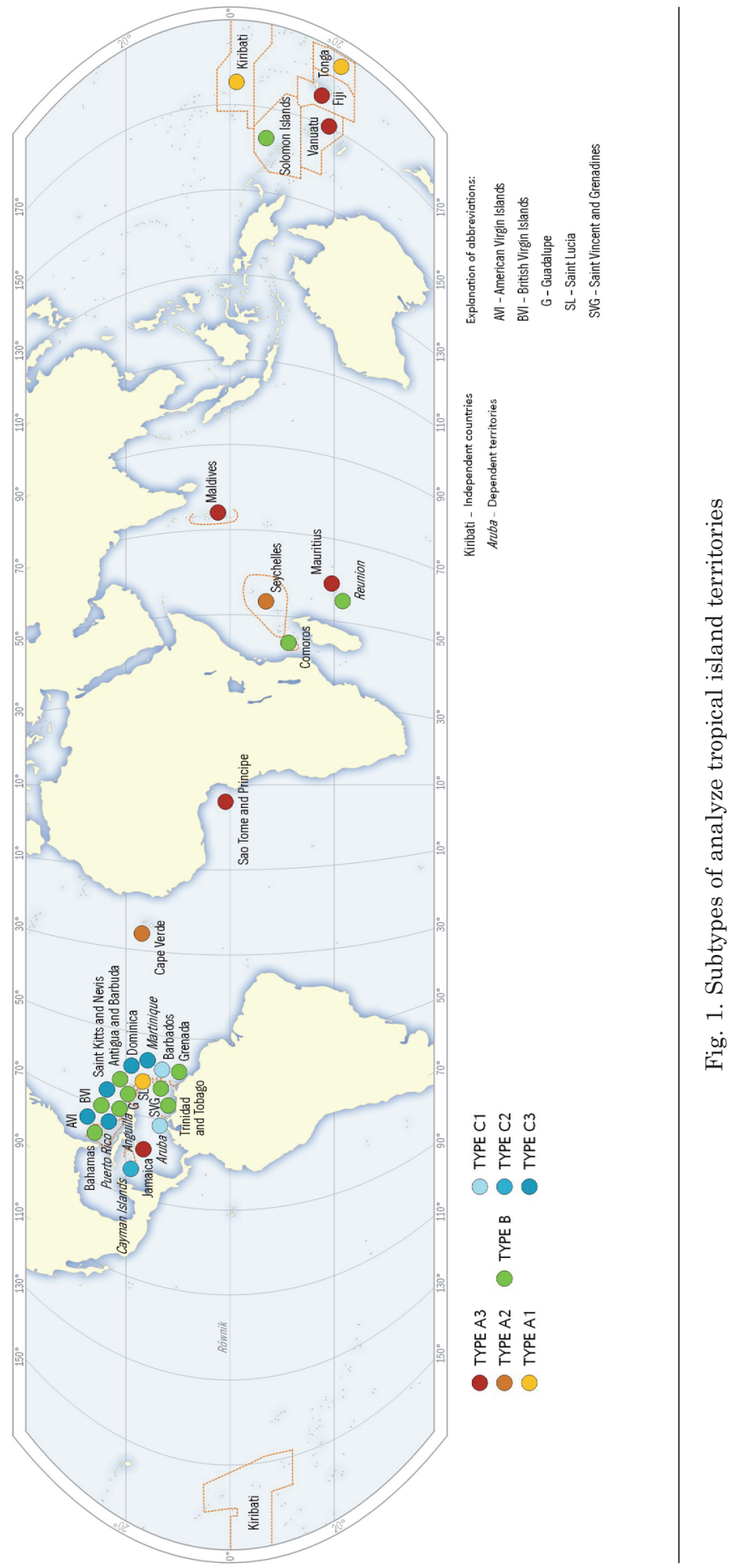


ratio, average or small isolation indicator, high urbanisation, not many independent countries and many dependent states, location: the Caribbean.

\section{Hierarchy of the conditions determining the economic importance of tourism}

The conditions determining the economic value of tourism were hierarchised on the basis of a variety of means for particular conditions among chosen types. The conditions were order by the value of deviation of average values for types $\mathrm{A}$ and $\mathrm{C}$ as compared to type B. (1. population, 2. surface area, 3. population density, 4. length of stay ratio, 5. diversification of economy ratio, 6. isolation indicator, 7. urbanisation).

Table 4. Deviation of average values in types A and C as compared to type B for the analysed conditions

\begin{tabular}{|l|c|c|c|c|}
\hline \multicolumn{1}{|c|}{ Conditions } & $\begin{array}{c}\text { Standard } \\
\text { deviation from } \\
\text { type A as } \\
\text { compared to } \\
\text { average values } \\
\text { in type B }\end{array}$ & $\begin{array}{c}\text { Deviation } \\
\text { from type C as } \\
\text { compared to } \\
\text { average values } \\
\text { in type B }\end{array}$ & $\begin{array}{c}\text { The sum of } \\
\text { modules of } \\
\text { standard } \\
\text { deviation from } \\
\text { average values }\end{array}$ & $\begin{array}{c}\text { Sequence of } \\
\text { conditions by } \\
\text { the value of } \\
\text { deviation from } \\
\text { average values }\end{array}$ \\
\hline $\begin{array}{l}\text { Diversification of } \\
\text { economy ratio }\end{array}$ & $44 \%$ & $-31 \%$ & $75 \%$ & 5 \\
\hline Surface area & $-50 \%$ & $-95 \%$ & $145 \%$ & 2 \\
\hline Population & $77 \%$ & $132 \%$ & $209 \%$ & 1 \\
\hline Population density & $49 \%$ & $75 \%$ & $124 \%$ & 3 \\
\hline Length of stay ratio & $-76 \%$ & $16 \%$ & $92 \%$ & 4 \\
\hline Isolation indicator & $58 \%$ & $-7 \%$ & $65 \%$ & 6 \\
\hline Urbanisation & $-25 \%$ & $26 \%$ & $51 \%$ & 7 \\
\hline
\end{tabular}

Table 5. The values of the chi-square test and the significance level for selected conditions, which can potentially affect classification into particular types

\begin{tabular}{|l|c|c|}
\hline \multicolumn{1}{|c|}{ Conditions } & $\begin{array}{c}\text { The value } \\
\text { of Chi-square test }\end{array}$ & Significance level \\
\hline Diversification of economy ratio & 5,932 & 0,204 \\
\hline Surface area & 7,977 & 0,092 \\
\hline Population & 4,636 & 0,327 \\
\hline Population density & 5,250 & 0,263 \\
\hline Length of stay ratio & 6,886 & 0,142 \\
\hline Isolation indicator & 14,932 & $0,005^{*}$ \\
\hline Urbanisation & 12,886 & $0,012^{*}$ \\
\hline Status & 8,950 & $0,011^{*}$ \\
\hline Geographical location & 15,455 & $0,017^{*}$ \\
\hline
\end{tabular}

* Correlation is significant at a level of 0.05 .

The hierarchy of conditions underpinning the share of tourism in the economy was developed on the basis of the differentiation of average values 
for each of the conditions for each type. It was verified by the Chi-square test, which was significant at the 0.01 level, to see if there is a statistically significant relation between types $\mathrm{A}, \mathrm{B}, \mathrm{C}$ and the chosen conditions. The Chi-square test was made for qualitative features - classification into the type and the selected conditions.

Conditions which were statistically significant included: geographical location, isolation indicator, urbanisation and status of the island territories. In turn, conditions which were not statistical significant were: surface area, length of stay ratio, diversification of economy, population and population density.

\section{PROBABLE INFLUENCE OF SELECTED CONDITIONS ON CLASSIFICATION INTO PARTICULAR TYPES}

The classification into particular types was influenced by the geographical location of tropical island territories. Possibly, this was due to the fact that the island territories located in the Caribbean (only territories located in this region were classified in type C) are located on cruise ships routes. They receive enormous numbers of one-day visitors who spend small amounts of money on the islands (they buy most of products and services on the ship). On the other hand, tropical island territories classified as type A (located in the Indian Ocean, the Pacific Ocean and the Eastern Atlantic) are characterised by longer stays (holiday tourism, qualified tourism and ecotourism). Tourists stay longer and spend more money.

Another condition affecting the classification of tropical island territories into particular types is the isolation indicator. The values of this indicator were high for type A. It could be due to the fact that tourists who chose more isolated territories are more wealthy. They spend more money on such travels. People rarely decide to travel such long distances but if they decide to do so, they stay longer and are willing to spend more. For tropical island territories in types B and C, the isolation indicator was smaller or average, which means that tourists often choose less isolated territories but for shorter and cheaper stays.

Another condition that has had an influence on the classification was urbanisation. In type A, we classified tropical island territories with average or small urbanisation, which could be due to the fact that people who live outside the city and are employed in the agriculture sector provide more products for the local economy. It is not necessary to import so many products from abroad, and this restricts the transfers of revenues from tourists abroad (Ashe, 2005, p. 2; Hjalager, 2007, pp. 473-438). In turn, type $\mathrm{C}$ groups territories with high urbanisation, which could be due to the fact that the majority of the population in those territories live in the cities, and the local economy is dominated by services, with a marginal share of other sectors. 
Another factor influencing the classification into particular types was the status of tropical island territories. Type A included only independent island territories. It may be due to the fact the independent countries may have their own tourism policy protecting the domestic tourism market. It is also possible to lower the tax for tourists services, introduce arrival tax, local taxes and other tourists taxes. All these may contribute to a greater share of tourism in the economy in proportion to the intensity of tourism movement. In turn, type B had more independent countries than dependent territories. It may be due to the fact that dependent territories have a bigger share of transfers form tourism revenues abroad.

Other conditions potentially influencing the classification into particular types were not statistically significant. The were described in order of the value of deviation from average values.

Population. Island territories in type A have mostly an average population. It could be due to the fact that more people might be interested in work in tourism. In turn in type $\mathrm{C}$ tropical island territories are characterised by a small number of tourists. Not all people who are economically active could work in tourism. It was often necessary to import workers who could work in low-paid jobs in the tourism industry (that is why there was a smaller share of employment in tourism economy than in proportion to the intensity of tourism movement).

Surface. In type A, we classified territories with an average or big surface area. It may be due to the fact that bigger island territories had more possibilities for developing new areas of economy, offering tourists more diversified products and forms of tourism (holiday tourism, qualified tourism, ecotourism). In turn, in type $\mathrm{C}$, there were tropical island territories with a small surface area. Similarly, they did not have diversified economy and were located on popular cruise ship routes.

Population density. Population density in type A was average or small. It may be due to the fact that, in such a population, a higher share of economically active people could work in tourism. In turn, in type $\mathrm{C}$, the population density was high, which means that they were usually small island territories. It may be due to the fact that a large number of people in small island territories could be involved only in tourism activities.

Length of stay ratio. Type A included territories with a small or average length of stay ratio. Those territories were characterised by a small number of days spent by visitors in proportion to the number of the population. Maybe for these tropical island territories came tourists for typical holiday and they spend more money. In turn, in types B and C, we classified territories with an average or high length of stay ratio. It may be explained by a considerable share of cruise passengers among their visitors.

Diversification of economy ratio. Type A included tropical island territories with a high or average diversification of economy ratio. It may be due to the fact that a more diversified economy would provide more products and services and there would be no need to import them. That means that 
transfers of revenues from tourism are smaller. In turn, in type C, we classified tropical island territories with a small or average diversification of economy ratio.

Case studies

- Three case studies of island territories with typical conditions were conducted for the purposes of the study: Mauritius, The Solomon Islands and The Cayman Islands. These territories exemplified each of the aforementioned types (A, B and C). After analysing the case studies, the following information was obtained:

- The following conditions are the most important for the variety of share of tourism in the economy: the status of tropical island territories and their geographical location. It is due to the fact that the independence of a country influences its possibility to have its own tourism policy. Tourism policy may result in smaller money transfers of revenues from tourism (Economic Impacts of Tourism, 2001, p. 3; Płocka, 2002, p. 135; Piraszewska, 2005, p. 272). The geographical location in the Indian Ocean and in the Pacific Ocean makes tourists stays in the islands longer, which means that they spend more money on islands.

- The geographical location of tropical island territories in the Caribbean is not connected with a higher share of tourism in the economy despite a high intensity of tourism movement, but with a considerable share of cruise tourism.

- The geographical location and the isolation indicator are factors which have an impact on the share of tourism in economy. The more isolated the tropical island territories, the more tourists decide to stay longer on such islands in order to compensate for the length of stay and the costs of travel. They also spend more money on the tropical islands that they visit.

- Urbanisation may influence the nature of tourism in some tropical island territories. That means it can also influence the amount of money spent and the share of money transfers from tourism.

\section{CONLUSIONS}

The aims of the study have been achieved because the existence of an average positive correlation between intensity of tourism movement and the share of tourism in the economy has been proved. That means the hypothesis formulated at the beginning of the study was confirmed. On the basis of the Chi-square test, it was assumed that, for the analysed tropical island territories, the following factors exert the greatest influence on the classification into particular types: geographical location, isolation indicator, urbanisation and status. The hypothesis about the crucial influence of the diversification of the economy on the share of tourism in the economy in proportion to the intensity of tourism movement was not confirmed. Moreover, 
on the basis of detailed case studies, the reasons why the above conditions have such an influence on the role of tourism in the economy of tropical island territories have been explained.

\section{REFERENCES}

Ashe W., 2005, Tourism investment as a tool for development and poverty reduction. The experience in Small Island Developing States (SIDS), Trade and Investment, 18-20 September, Barbados, pp. 1-5

Compendium of Tourism Statistics, 2006, World Tourism Organization, Madrid.

Economic Impacts of Tourism, 2001, United Nations Environment Programme Tourism.

Hjalager A. M., 2007, Stages in the economic globalization of tourism, Annals of Tourism Research, Vol. 34, No. 2, pp. 437-457.

http://www.unstats.un.org/unsd/demographic/products/socind/population.htm (13.08.2006) United Nations Statistical Division - Demographic and Social Statistics

Piraszewska K., 2005, Neokolonializm turystyczny Północy wobec Południa - wybrane przykłady [Tourist neo-colonialism of the north towards the south], [in:] Solarz M. (ed.) Pótnoc wobec Potudnia. Potudnie wobec Pótnocy [The north vs. the south. The south vs. the North], Oficyna Wydawnicza ASPRA-JR, Warsaw, pp. 269-276.

Płocka J., 2002, Wybrane zagadnienia z zagospodarowania turystycznego, czesść I [Selected topics in tourism management, part I], Centrum Kształcenia Ustawicznego, Torun.

Recommendations on Tourism Statistics, 1994, World Tourism Organization, United Nations, 1994, Madrid.

World, Travel and tourism sowing the seeds of growth, The 2005 Travel and Tourism Economic Research, 2005, World Travel and Tourism Council, Oxford. 